\title{
Estimation of the distribution of eastern and western marginal localities of plant species in the Southern Tuva Mountain Chain
}

\author{
Igor' A. Artemov* \\ Central Siberian Botanical Garden, SB RAS, 630090 Novosibirsk, Russia
}

\begin{abstract}
The increase of number of the western marginal plant localities is revealed in the western part of the Southern Tuva Mountain Chain, from the Mongun-Taiga Massif to the Sengilen Mt. Range, in comparison with the eastern and central parts of this mountain chain. The increased number of the eastern marginal plant localities is revealed in the eastern part of the mountain chain in comparison of its central part. Such distribution of marginal localities suggests the Southern Tuva Mountain Chain to be a corridor for the westward and eastward migration of plant species.
\end{abstract}

\section{Introduction}

The Tyva Republic is limited from the south by the mountain chain which is the world watershed among the Arctic Ocean basin and the drainless area of the Central Asia. This mountain chain includes, from the west to the east, Mongun-Taiga Massif, Tsagan-Shibetu, Western Tannu-Ola, Eastern Tannu-Ola, Horumnug-Taiga and Sengilen Mt. Ranges. It acts as an outpost of the southward distribution of the Siberian mountain taiga landscapes and of the northward distribution of the Mongolian desert steppe landscapes [1]. The Tannu-Ola Mt. Ranges, which are parts of the Southern Tuva Mountain Chain, also represent a botanical-geographical boundary separating the depressions of Central Tuva and depressions of Southern Tuva and Mongolia. These ranges are an obstacle for the southward spread of some steppe species and act as a barrier for humid air masses. As a result, conditions are created for penetration of certain forest and meadow species into the Tuvinian Depression from the mountain framing of this depression [2]. At the same time, it is of interest whether the Southern Tuva Mountain Chain form a structure that not only prevent latitudinal migration, but also promote the longitudinal migration of plant species. The article is applied to estimate westward and eastward migration of plant species in the Southern Tuva Mountain Chain.

\section{Material and methods}

The numbers of the western and eastern marginal localities of plant species are used for estimation of the level of species migration in western and eastern directions. If the number

\footnotetext{
* Corresponding author: $\underline{\text { artemov_1 @ mail.ru }}$
} 
of western marginal localities is more in the western part of sublatitudinal mountain chain in comparison of the number of marginal localities in the central and eastern parts of the chain, then author assumes that species during migration along the mountain chain had not any substantional obstacles and the chain presented a corridor for plant species migration. The same assumption was accepted for estimation of eastward species migration.

The published dot distribution maps of 2569 vascular plant species and subspecies of Siberian flora [3] were used for revealing western and eastern marginal localities. The localities in dot distribution maps were geocoded by means of Geographic Information System ArcView GIS 3.2a (registration number is 843181116338) and the module ArcView Spatial Analyst 2.0a (registration number is 849601104159). The procedure and results of geocoding were published in Global Biodiversity Information Facility (GBIF) [4].

The coordinates of geocoded localities and the corresponding names of taxa were entered into the Localities Database in MS Access. Then, for every species or subspecies presented by not less than two dots, western and eastern marginal localities were entered in Marginal Localities Database. The selection of marginal localities were made by means of a program writen by author in Visual Basic for Applications.

The marginal localities, embraced by the frame with sides $\mathrm{N} 50^{\circ}-51.5^{\circ}$ and $\mathrm{E} 89^{\circ}-98^{\circ}$ where the Southern Tuva Mountain Chain are situated, were selected from Marginal Localities Database. Some territories besides the Southern Tuva Mountain Chain were partially embraced by the frame as well: the Tuvinian and Ubsunur Depressions, Alash and Kaa-Khem Highlands. Localities from these territories were excluded from consideration. Many species from the Southern Tuva have rather vast ranges, which extend beyond the boundaries of Siberia. Such species, which extend westward of the western marginal localities in Siberia, for example in the Middle Asia [3], were excluded from the consideration as well. Also the species which occurs eastward of the eastern marginal localities in Siberia were excluded from the consideration as well. They are species which have been registered for botanical-geographical districts of the Central and Eastern Mongolia: Prikhubsugulskiy, Hangaiskiy and others [5]. Several species were not taken into account because the results of geocoding of their dot distribudion maps [3] were not in accordance with the species distribution by Tuvinian nature districts[6]. They are for example lowland species of the Erzinskiy steppe nature district [6] which were geocoded as growing at the nearby situated Sengilen Mt. Range: Hordeum nevskianum Bowden, Stipa anomala P. A. Smirn. = S. pennata subsp. sabulosa $($ Pacz.) Tzvelev, Limonium coralloides (Tausch) Lincz. and others. Finally 16 western and 33 eastern marginal localities of plant species/subspecies were selected for the Southern Tuva Mountain Chain.

The number of the marginal localities in the Western, Central and Eastern parts of the Southern Tuva Mountain Chain were compared for the estimation of westward and eastward migration of plant species. The division of the mountain chain to three roughly equal parts were accepted by two main automobile roads which cross the chain (Chadan Handagaity and Balgazyn - Samagaltay):

western part - the Mongun-Taiga Massif, the Tsagan-Shibetu Mt. Range, the western part of the Western Tannu-Ola Mt. Range;

central part - the eastern part of the Western Tannu-Ola Mt. Range, the Eastern TannuOla Mt. Range;

eastern part - the Horumnug-Taiga and Sengilen Mt. Ranges.

GIS NextGIS QGIS was used for visualisation of marginal localities of plant species on the map. 


\section{Results and discussion}

The distribution of the western marginal localities in the Southern Tuva Mountain Chain shows the westward increase of their number (fig. 1): one locality is revealed for the eastern part of the mountain chain - Dracocephalum fragile Turcz. ex Benth.; 5 localities are revealed for the central part - Oxytropis filiformis DC., O. oxyphylla (Pall.) DC., Hedysarum fruticosum Pall., H. sangilense Krasnob. et Timokhina, Pedicularis rubens Bunge; 10 localities are revealed for the western part - Elymus confusus (Roshev.) Tzvelev, Allium mongolicum Regel, Potentilla tericholica Sobolevsk., Astragalus monophyllus Bunge ex Maxim., Hedysarum inundatum Turcz., Euphorbia potaninii Prokh., Lappula anisacantha (Turcz. ex Bunge) Gürke, Asterothamnus heteropappoides Novopokr., Scorzonera ikonnikovii Lipsch. et Krasch., Hieracium sangilense N. N. Tupitsyna.

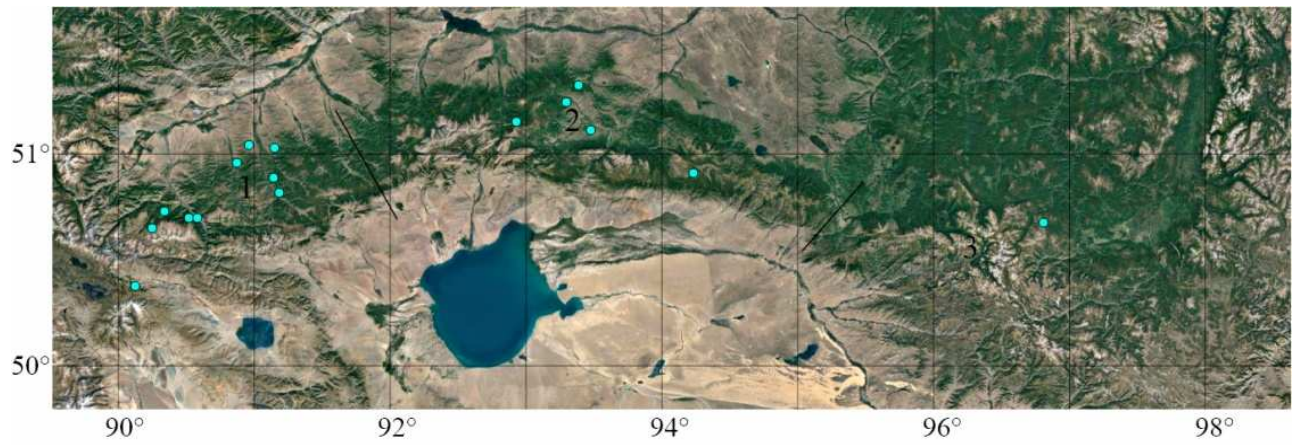

Fig. 1. Siberian western marginal localities of plant species in the Southern Tuva Mountain Chain.

1 - western part of the Southern Tuva Mountain Chain;

2 - central part of the Southern Tuva Mountain Chain;

3 - eastern part Southern Tuva Mountain Chain.

Absence of the obvious clusters of the western marginal localities in the Southern Tuva Mountain Chain allows to suppose the absense of the floristic boundaries for westward migration of plant species. The increase of the number of the western marginal localities to the western part of the Southern Tuva Mountain Chain apparently indicates that the nature conditions in the central and eastern parts of the mountain chain do not disturb westward migration of plant species along the chain.

The distribution of the eastern marginal localities in the Southern Tuva Mountain Chain shows their slight predominance in the eastern part of the mountain chain as compared with its western part and their significant predominance as compared with its central part (fig. 2): 14 eastern marginal localities are revealed for the western part of the mountain chain Salix alatavica Kar. et Kir. ex Stschegl., Ranunculus akkemensis A. V. Polozhii et N. V. Revyakina, Papaver canescens Tolmatch., Rhodiola algida (Ledeb.) Fisch. et C. A. Mey., $R$. coccinea (Royle) A. Boriss., Astragalus schanginianus Pall., Biebersteinia odora Royle, Stenocoelium athamantoides (M. Bieb.) Ledeb., Dracocephalum bungeanum Schischk. et Serg., Doronicum oblongifolium DC., D. turkestanicum Cavillier, Saussurea orgaadayi V. M. Khanminchun et I. M. Krasnoborov, Taraxacum krylovii A. A. Krasnikov et V. M. Khanminchun, T. pingue Schischk.; 3 eastern marginal localities are revealed for the central part - Allium pumilum Vved., Sedum populifolium Pall., Cirsium komarovii subsp. schischkinii (Seng.) O. S. Zhirova; 16 eastern marginal localities are revealed for the eastern part - Allium tuvinicum (N. Friesen) N. Friesen, Iris bloudowii Ledeb., Chenopodium iljinii Golosk., Ceratocarpus arenarius L., Rhodiola krylovii A. V. Polozii et N. V. Revyakina, Potentilla approximata Bunge, P. tericholica Sobolevsk., Oxytropis saposhnikovii Krylov, Linum pallescens Bunge, Euphorbia tshuiensis (Prokh.) Serg. ex 
Krylov, Leonurus tataricus L., Thymus petraeus Serg., T. schischkinii Serg., Valeriana martjanovii Krylov, Taraxacum pseudoatratum Orazova, T. tuvense I. M. Krasnoborov et A. A. Krasnikov.

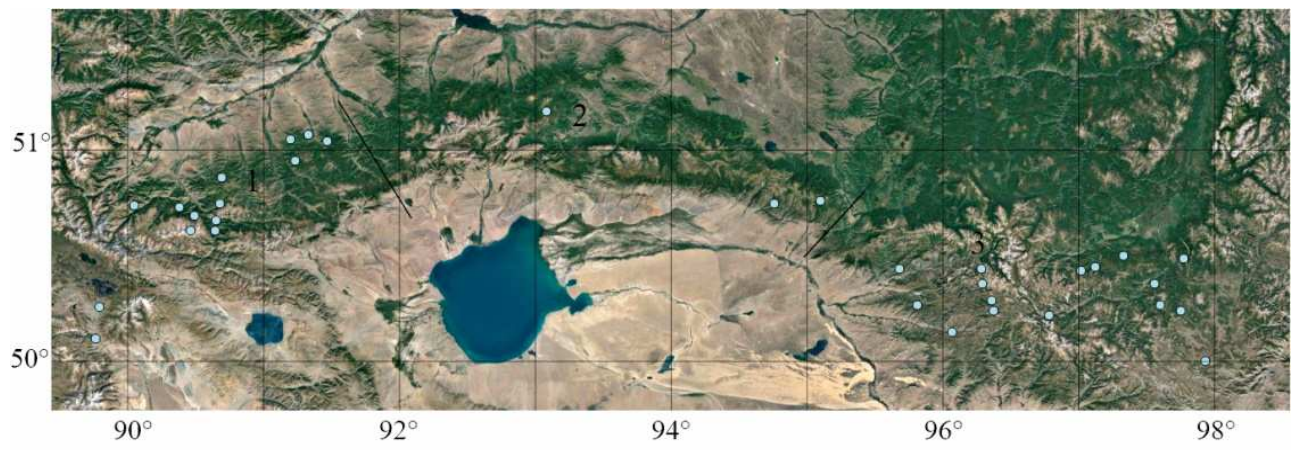

Fig. 2. Siberian eastern marginal localities of plant species in the Southern Tuva Mountain Chain.

1 - western part of the Southern Tuva Mountain Chain;

2 - central part of the Southern Tuva Mountain Chain;

3 - eastern part Southern Tuva Mountain Chain.

The lack of obvious clusters of the eastern marginal localities of plant species in the Southern Tuva Mountain Chain demonstrates the absense of the floristic boundaries on the way of the eastward migration of plant species. The increased number of the eastern marginal localities in the eastern part of the mountain chain in comparison to its central part sugests the Southern Tuva Mountain Chain to be a corridor for eastward migration of plant species.

It should be point out that more than 20 species which are recorded in the HorumnugTaiga and Sengilen Mt. Ranges by the results of geocoding are indicated in the Flora of Mongolia [5] for the Mongolian nature districts Prikhubsugulskiy and Hangaiskiy, which are situated eastward of this ranges. They are Koeleria altaica (Domin) Krylov, Stipa orientalis Trin., Aconitum decipiens Vorosch. et Anfalov, Ranunculus lasiocarpus C. A. Mey., Dracocephalum imberbe Bunge, D. origanoides Ledeb., Lonicera microphylla Willd. ex Roem. et Schult. and others. This allows to accept the eastern part of the Southern Tuva Mountain Chain as a migration zone at least for these species.

\section{References}

1. Natural resources of the Tyva Respublic, 1 (Garamond, Novosibirsk, 2018)

2. I.A. Artemov, The flora of Asian Russia, 2, 72-78 (2015)

3. Flora of Siberia, 1-13 (Novosibirsk, 1987-1997)

4. I. Artemov, A. Egorova, Locations of plants on dot distribution maps in the Flora of Siberia (Flora Sibiraea, 1987-1997). Version 1.2. Central Siberian Botanical Garden SB RAS. Occurrence dataset (2021)

5. I. A. Gubanov Conspectus of flora of Outer Mongolia (vascular plants) (Moscow, Valang, 1996)

6. Plant identification guide of the Tyva Respublic (Novosibirsk, 2007) 